\title{
Egy „elképzelt” középosztály és a lokalitás „valósága” \\ Tanodaprogramok mozgásterei egy zsugorodó városban ${ }^{1}$
}

\author{
Kovai Cecília \\ https://doi.org/10.51624/SzocSzemle.2020.2.4 \\ Beérkezés: 2020. 06. 15. \\ Átdolgozott változat beérkezése: 2020. 10. 06. \\ Elfogadás: 2020. 10. 26.
}

\begin{abstract}
Összefoglaló: A tanulmány azt vizsgálja, hogy a hátrányos helyzetủ roma gyermekek társadalmi mobilitását segítő tanodaprogramok hogyan valósulnak meg egy zsugorodó város társadalmi viszonyaiban. A cikk az antropológiai fejlesztéskritika egyik alaptételét használja, vagyis hogy a fejlesztői projektek megvalósulása egy örökös egyeztetési folyamat eredménye a projekt „küldetését” képviselő szakmai stáb és a célcsoport különböző szereplői között. A tanulmány egy volt ipari középváros két tanodáján keresztül mutatja be az egyeztetési folyamatok különböző módjait. A tanodák esetében az egyeztetési folyamat fő kihívása annak az ellentmondásnak a feloldása, hogy a tanodaprogramok egyéni életutakra koncentráló középosztályosodás projektje olyan strukturális (szélesebb társadalmi, gazdasági, politikai folyamatok által teremtett) akadályokba ütközik, amelyeknek kezelésére a tanodáknak nincsenek erőforrásaik. A cikkem azt vizsgája, hogy ennek az ellentmondásnak a kezelése hogyan befolyásolja a tanodaprogramok megvalósulását egy zsugorodó város társadalmi kontextusában.
\end{abstract}

Kulcsszavak: fejlesztések, társadalmi mobilitás, etnikai különbségtétel, zsugorodó városok

\section{Bevezetés}

A cikkem azt mutatja be, hogy a hátrányos helyzetű roma népesség társadalmi mobilitását célzó tanodaprogramok ${ }^{2}$ hogyan valósulnak meg az általunk vizsgált zsugorodó

1 A tanulmány az „Állami beavatkozások és fejlesztői tevékenységek hatása hátrányos helyzetű roma közösségekre" címú (PD 121058 számú projekt), a Nemzeti Kutatási Fejlesztési és Innovációs Alap posztdoktori pályázati programjának keretében készült. A terepmunka és a posztdoktori kutatás kapcsolódik a „Helyi közpolitikák és marginalitás (újra) termelődése hanyatló városokban" (119465) címú, Virág Tünde által vezetett NKFIH kutatáshoz.

2 A tanoda civil vagy egyházi szervezetek által működtetett intézmény, amely délutáni foglalkozásokkal segíti elő hátrányos helyzetű, főleg roma gyermekek iskolai előmenetelét és társadalmi mobilitását. A fentiek sok esetben együtt járnak a roma etnikai identitás erősítésével is. Tanodák föként olyan településeken, településrészeken müködnek, ahol magas a halmozottan hátrányos helyzetủ roma gyermekek száma. A tanodák célkitűzéseik szerint az iskolai eredmények javulását nem pusztán a szaktantárgyi korrepetálás eszközeivel kívánják elérni, hanem jóval komplexebb módszerekkel, hiszen a gyermekek iskolai teljesítményét holisztikusan értelmezik, vagyis azt a gyermekek elönytelen társadalmi helyzetének következményének tekintik. Következésképpen a tanodák a korrepetálás mellett számos más, a gyermekek helyzetét kompenzáló programot ajánlanak: kezdve a támogató közösségtől a szabadidős programokon át a különböző fejlesztői tevékenységekig. 
városok társadalmi kontextusaiban. A tanulmány az antropológiai fejlesztéskritika egyik alaptételét használva abból indul ki, hogy ezek a programok eleve egy ellentmondásos helyzetbe kerülnek, hiszen a gyerekek középosztályosodását célzó projektjük olyan strukturális (szélesebb társadalmi, gazdasági, politikai folyamatok által teremtett) akadályokba ütközik, amelyeknek kezelésére sem hivatásuk, sem kompetenciáik nincsenek. A cikkem azt vizsgája, hogy ezek az ellentmondások hogyan hatnak a tanodák müködésére az általunk vizsgált zsugorodó város viszonyai között.

A tanulmány etnográfiai terepmunkán alapul, amely 2017 és 2019 között zajlott egy volt ipari középváros két tanodájában. Ebben a két évben több hónapos résztvevő megfigyelést végeztem a tanodákban és a célcsoport közösségében, több mint 30 félig strukturált interjút készítettem, valamint informális beszélgetéseket folyattam a tanodák szakmai vezetőivel, dolgozóival, szülőkkel és gyerekekkel. Fontos azonban megjegyezni, hogy a résztvevő megfigyelés, a rögzített interjúzás, a fókuszcsoportos beszélgetések és az informálisabb társalgások kevert módszertana jelentős módszertani dilemmákat hozott a kutatás során. Résztvevő megfigyelőként ugyanis a kutató abban érdekelt, hogy jelenléte minél inkább beolvadjon az adott közeg mindennapjainak menetébe, ezért többnyire igyekeztem háttérbe húzódni vagy egyfajta önkéntesként segíteni a tanodák hétköznapi múködését. Ebben a kvázi feltűnésmentes üzemmódban könnyen megfigyelhetőek a hétköznapi gyakorlatok, párbeszédek, és lazább hangvételű informális beszélgetések is egyszerübben folytathatóak. A résztvevő megfigyelés fenti módon történő alkalmazását azonban igencsak megzavarták a rögzített, négyszemközti interjús vagy fókuszcsoportos helyzetek. Az interjúk egyrészt hivatalosabb jellegüknél fogva egyfajta „hivatalnok”, „hatósági személy” szerepébe emeltek, másrészt pedig az elhangzó, ráadásul rögzített bensőségesebb információk kellemetlenné tették további jelenlétemet az érintettek szemében (vö. Németh 2015). A helyzetet csak tovább bonyolította, hogy a tanodák mellett a városi szegénynegyedben is végeztem terepmunkát, hiszen többnyire onnan kerültek ki a tanodás gyerekek. Sok esetben az otthonukban csináltam interjúkat a szülőkkel, akik aztán nehezen tudták hova tenni, hogy a „kutató hölgy” miért lóg még esti órákban is a negyedben. A „tulajdonképpen ki vagy te?” kérdését, amely valószínúleg elég sokakat foglalkoztatott a terepen, végül az utcán bandázó gyerekek tették fel nekem. A válaszom mindig más interpretációkat szült az érintettekben, mindenesetre ezek az értelmezések arra sarkaltak, hogy módszertani repertoáromat az adott helyzethez igazítsam, tekintetbe véve az adatközlők pozícióját és érzékenységeit. Vagyis egyrészt azokkal készítettem rögzített interjúkat, akik hivatalos pozíciót töltöttek be (szakmai vezetők), így számukra nem jelentett kihívást az efféle helyzet, másrészt azokkal, akiket a hétköznapokban nehezebben lehetett elérni. Míg másokkal, akikkel a mindennapi interakciók lehetségesek voltak, inkább az informális beszélgetést választottam, majd magányos óráimban jegyzeteket készítettem (vö. Németh 2017). Mindezek mellett a tanodák vizsgálata eleve kihívást jelentett, hiszen ezeket az intézményeket rengeteg adminisztrációs és strukturális 
teher nyomja, így jelenlétem sok esetben egyfajta ellenőrzésként értelmeződött. Ezeket az aggodalmakat igyekeztem tudományos magyarázattal feloldani, vagyis hogy a tanodák tevékenységét szélesebb összefüggésben vizsgálom, és nem tisztem megítélni a szakmai munkájukat. Magyarázatom nem volt túl hatásos, inkább a személyes jelenlétemből fakadó, kialakuló informális, bizalmi kapcsolatok segítettek. E tanulmányban is tartom magam azonban „tudományos magyarázatomhoz”, vagyis hogy cikkem célja nem a vizsgált tanodaprogramok „sikerességének” megítélése, hanem a tanodaprogramnak mint fejlesztői tevékenységnek a szélesebb elméleti és strukturális keretbe helyezése, mozgástereiknek és kényszereiknek értelmezése.

A tanodaprogramok múködésének értelmezéséhez többek között a nemzetközi fejlesztéseket vizsgáló kritikai irodalom alapvetéseit használom. Fő állításuk, hogy a fejlesztői tevékenységek maguk is részei annak az egyenlőtlenségeket termelő struktúrának, amely a fejlesztendő csoportok előnytelen helyzetét létrehozzák. Ez nem is lehetne másként, hiszen müködésük ellehetetlenülne, ha nem illeszkednének a létező társadalmi, gazdasági, politikai erőviszonyok feltételeihez. A fejlesztői diskurzus azonban többnyire ignorálja azokat a strukturális kényszereket, amelyek mind a fejlesztők, mind a fejlesztendők mozgástereit meghatározzák. Ennek következménye, hogy fejlesztések csak nagyon limitált mértékben tudnak eredményeket elérni, sőt legtöbb esetben maguk is e meghatározottságok logikája szerint múködnek, vagy csupán a bürokratikus kontroll burjánzásához járulnak hozzá (Annist 2005; Elyachar 2005; Escobar 1995; Ferguson 1994, 2015; Mitchell 2002; Mosse 2005).

Habár a magyarországi tanodák egy nagyon különböző társadalmi kontextus fejlesztői tevékenységei, mint amelyekről a fenti kritikák születtek, mégis számos ponton használhatóak ezek a kritikai megállapítások. Az első tanodák a 90-es évek közepén jöttek létre kimondottan civil kezdeményezésekként, többnyire önkéntes munkából és adományokból tartották fenn magukat. Missziójuk a kezdettől fogva az volt, hogy a hivatalos, állami oktatási rendszer kárvallottjait, hátrányos helyzetú roma gyermekeket készítsenek fel a továbbtanulásra, ezzel elősegítve a társadalmi mobilitásukat. Az ún. tanodamozgalom első úttörői deklarálták, hogy az államtól és az iskolarendszertől függetlenül kívánnak múködni, és egyfajta „grassroot” mozgalomként a szülőkkel és a hátrányos helyzetű közösségekkel való kapcsolattartásra építik intézményeiket. A tanodák létrejöttében az osztályalapú etnikai kirekesztés és különbségtétel kritikája elsődleges szerepet játszott. A tanodamozgalom „cigány” programként definiálta magát egy olyan társadalmi környezetben, ahol a cigányság elsősorban stigmát jelentett, amelytől a társadalmi mobilitás jobb esetben megszabadít. A tanodák ezzel szemben a cigány identitást és a társadalmi mobilitást összekapcsolták, az előbbit mint vállalható erőforrást jelenítették meg. A tanodamozgalom maga tehát egyrészt egyfajta rendszerkritikai aktusként értelmezhető, másrészt pedig egy korszak jellegzetes termékeként, hiszen egy olyan időszakban született, amikor nem pusztán a civil szervezetek konjunktúrája zajlott, hanem a civil társadalom eszméje is fénykorát élte. A 2000-es évek elejére azonban az ado- 
mány- és önkéntes alapú fenntartás kifulladt, a növekvő számban létrejövő tanodák finanszírozását immár az állam vállalta, ez ún. projektalapú finanszírozást jelentett, amely új lehetőségeket és egyúttal kényszerpályákat hozott a tanodák számára. Mindeközben a fent leírt misszió többé-kevésbé állandó maradt, csupán új feltételek között kellett megvalósítani (Baráth 2016; Fejes 2016; Kende 2018; Szőke 2016).

A tanodaprogramok tehát nem ignorálják teljesen a strukturális kényszereket, hiszen a gyermekek gyenge iskolai teljesítményét egyrészt az előnytelen társadalmi helyzet következményeként értelmezik, másrészt az oktatási intézmények diszfunkciójának látják (Kende 2018; L. Ritók 2016; Szőke 2016; Szűcs 2015). Ugyanakkor a tanodaprogramok megvalósulását is nagyban meghatározza az a fejlesztői tevékenységeket általában jellemző feltételrendszer, miszerint úgy kell változásokat elérniük, hogy az egyenlőtlenségeket termelő strukturális körülmények alakítására nincs módjuk, sőt maguk is kénytelenek azokhoz illeszkedni. Elég, ha csak a tanodaprogramok finanszírozására gondolunk, amely az állami szervek döntésén múlik, és maximum három évre teszi lehetővé a kiszámítható működést.

A tanodaprogramokat tehát a strukturális feltételek kontextusában érdemes vizsgálni, ezzel párhuzamosan pedig azt célszerủ megnézni, hogy a konkrét programok hogyan kezelik, interpretálják ezeket a kényszereket megvalósulásuk során. A tanodaprogramok célkitűzéseiben a hátrányos társadalmi helyzet olyan adottságként jelenik meg, amely a tanodák segítségével egyéni erőfeszítések révén legyőzhető. Hasonlóképpen az elérni kívánt középosztálybeli pozíció is úgy tûnik fel, mint amely független az azt lehetővé tevő társadalmi viszonyoktól. A tanodáknak tehát egy nehezen feloldható ellentmondás feszítésében kell működniük, amelynek a lényege az, hogy a hátrányos helyzetű gyermekek társadalmi mobilitását elsősorban egyéni erőfeszítések révén hivatottak elérni, miközben annak lehetőségeit társadalmi, gazdasági, politikai (strukturális) kényszerek határozzák meg. A fentiek következtében a fejlesztői munka sok esetben folyamatos kudarcként, egyfajta sziszifuszi küzdelemként jelenhet meg az azt végzők között, amely során a tanodaprogramok missziójának célkitǔzéseit szinte lehetetlen megvalósítani.

A fejlesztéskritika egy jelentős irányzata azonban éppen a „siker” fogalmát, valamint a policy (esetünkben misszió vagy célkitűzés) és a megvalósulás viszonyát értelmezi újra (Annist 2005; Ferguson 2015; Mitchell 2002; Mosse 2005). David Mosse (2005) szerint nem a policyn múlik a fejlesztői programok megvalósulásának mikéntje, hiszen az folyamatos megvitatás alatt áll. A szereplők a projektek célkitúzéseit sok esetben ignorálják, ellenállnak neki, taktikailag használják, nem hivatalos célokat követnek a hivatalosak helyett, és mindannyian a saját pozíciójukból fakadó érdekeik szerint teszik ezt. A programok mindennapi gyakorlatai során tehát különböző érdekeket, szempontokat, diskurzusokat kell összeegyeztetni. A fejlesztés valójában ezen összegegyeztetések folyamata. Donorok, tanácsadók, programvezetők, szakemberek, projektmunkások csak akkor képesek befolyást gyakorolni, ha a javaslataik, elképzeléseik lefordíthatóak az érintettek vagy bármely résztvevő 
saját szándékaira, céljaira, ambícióira. Az igazi kérdés tehát nem az, hogy a policy sikeres programot tesz-e lehetővé, hanem az, hogy hogyan termelődik a „siker” a megvalósulás során. Valójában egy projekt nem azért müködik, mert a policyból realitás lesz, hanem mert a policy-modell lehetővé teszi az események közös értelmezését. A „siker” akkor következik be, ha a szereplők találnak egy domináns, működő interpretációt, amely a projektet értelemmel ruházza fel számukra (Mosse 2005).

Hasonlóképpen a tanodaprogramok esetében sem az fő a kérdésünk, hogy egyes programok mennyire hűen követik az eredeti misszió céljait, hanem az, hogyan zajlik ez az egyeztetési folyamat, hogyan lesznek összehangolhatóak a különböző résztvevők érdekei, értékei és ambíciói. A Mosse által leírt egyeztetési folyamat fő kihívása pedig a tanodák esetében az eredeti misszió célja, vagyis a középosztályosítási projekt megvalósítása egyéni erőfeszítéseken keresztül, és a „strukturális realitás”, vagyis a célcsoportot előnytelen pozícióban tartó gazdasági, politikai folyamatok között feszülő ellentmondás feloldása (vö. Németh 2020). A tanodáknak ezt az ellentmondást kell kezelniük valahogyan azért, hogy egyáltalán megvalósulhassanak. Ez az ellentmondás különösen erős egy periférikus helyzetű, volt ipari középváros esetében, hiszen a középosztálybeli habitus elsajátítását a tanodák egy olyan társadalmi kontextusban hivatottak érvényesíteni, amely csak igen korlátozott mértékben teszi lehetővé e középosztályi pozíció elfoglalását. Az egyeztetési folyamatokat tehát mindig az adott strukturális kontextusban uralkodó viszonyrendszerek alakítják, amelyek esetünkben egyrészt egy zsugorodó, volt ipari középváros strukturális körülményeit, másrészt az osztályhelyzettel összefüggő cigány-magyar különbségtétel működését jelentik.

Tanulmányomban egy volt iparváros két tanodáján keresztül mutatom be az egyeztetési folyamatok különböző módjait. A tanodák két helyi roma egyesület keretében múködnek, az egyeztetési folyamatok alakulásában tehát kiemelt szerepet játszanak a hátrányos helyzetű roma népességhez kötődő intézményrendszerek. Az egyik tanoda (Kezdő Szikra) a 90-es években induló civil szervezetek konjunktúrájához kapcsolódik, a civil társadalom erősítésének és szükségességének eszméjéhez köti a középosztályosodási törekvéseket. Míg a másik (Roma Hajnal) szintén a 90-es években induló roma kisebbségi politika intézményi világához kötődik, amelyben az érdekképviselet csak a pártpolitika logikáján és erőterén belül képzelhető el. Az esettanulmányokban azt mutatom be, hogy e különbözőségek hogyan alakítják az egyeztetési folyamatokat a szereplők között a program megvalósulása során. Mindezek előtt azonban mindenképp szükséges megvizsgálni az osztályalapú etnikai különbségtétel általános jellemzőit és lokális megjelenését, hiszen ez az a legfőbb strukturális kényszer, amely a tanodák mozgástereit esetünkben meghatározza.

\section{Cigányság és osztályhelyzet}

Mindenekelőtt fontos megjegyezni, hogy az etnicitás és az osztálypozíció összefonódása nemcsak a cigányságra és nem is csak Magyarországra jellemző jelenség, hanem egy olyan rendszerszintű folyamat, amely által határ képződik a formális fog- 
lalkoztatásban részt vevők, valamint az azon kívül vagy abban csak időszakosan tevékenykedő tömegek között (Boatcă 2015; Quijano 2000; Rajaram 2018; Wallerstein 2000). Az általunk vizsgált társadalmi közegekben az előbbi rendre a „magyar”, míg az utóbbi a „cigány” pozícióhoz társul, tehát az osztályviszonyok egyenlőtlenségei az etnikai hierarchia múködésével is járnak. A tanodáink „célcsoportjának” ingatag strukturális helyzete szintén abból fakad, hogy a formális munkaerőpiac vagy nem szívja fel őket, vagy csak igen nehezített körülmények között ad helyet számukra. Tehát bizonyos értelemben pozíciójuk az ún. „felesleges” vagy „többlet”-népesség fogalmával írható le. Ahogy azonban számos szerző írja, e „felesleges” népesség nincs kizárva a kapitalista termelési rendszerből, csupán annak egy privilegizáltabb szegmenséből, a formális, stabil bérmunkából. Valójában ez a népesség éppen kizáratása által részese a termelésnek, a munka olcsó, könnyen mozgatható és kizsákmányolható tartalékseregeként (Dunaway 2018 [2012]; van der Linden 2001; Rajaram 2018; Sanyal 2007; Wallerstein 2000). E szerzők azonban azt is hangsúlyozzák, hogy e réteg gyakran rasszizált vagy etnicizált népesség, a faji vagy etnikai hovatartozás az előnytelen strukturális pozíció esszencialista igazolásaként működik, az osztályhatárok stabilizálásaként (Boatcă 2015, Rajaram 2018, Quijano 2000, Wallerstein 2000). Az osztályhelyzet rasszizálásának/etnicizálásának e globális léptékben zajló folyamata közép-kelet európai kontextusban elsősorban „cigánykérdésként” jelenik meg (Efremova 2012; Grill 2018; Kovai 2017; Petrovici-Rat-Simionca-Vincze 2019; Rajaram 2018; Szombati 2018). Vagyis magyarországi esetekben, ahogy az általunk vizsgált városban is, az osztályviszonyok egyenlőtlenségei a „cigány”-„magyar” etnikai különbségtétellel erősödhetnek meg.

Ugyanakkor az etnicitás és az osztályhelyzet közötti megfelelés szigorúsága nem mindig és mindenhol azonos mértékü. E célcsoportok társadalmi helyzetét ugyanis esetünkben leginkább a formális, állandó bérmunka expanziójának és visszahúzódásának ciklikus mozgásai alakítják. Míg egy felívelő gazdasági ciklusban e csoportoknak van némi esélyük betagozódni a formális bérmunka legalsóbb szintjeire, addig a válságok idején kiszorulnak onnan. Ezt a hullámzást az osztályalapú etnikai különbségtétel működése is követi. Egy konjunktúraciklusban a társadalmi mobilitás csatornái is jobban megnyílnak, amelynek nyomán az etnikai különbségtétel kirekesztő mechanizmusai sem érvényesülnek olyan nagy erôvel. Úgy tûnhet, hogy ebben az időszakban az egyéni erőfeszítések és a strukturális körülmények nem ellentmondásban, hanem összhangban állnak egymással, így aztán a tanodaprogramok is több „sikert” könyvelhetnek el. A strukturális körülmények kedvezőtlenebbre fordulásával azonban a tanodák „sikerhez” vezető útja is rögösebbé válhat, vagy egyszerűen „siker” fogalma értékelődik át az egyeztetési folyamatok során.

A tanodáknak tehát e rendszerszintű folyamatok hatalmas erőfölényében kellene teljesíteni az egyének középosztályosodásának misszióját. A tanodák hivatása tulajdonképpen az, hogy az etnikailag stigmatizált munka tartalékseregéből minél több gyerek küzdje fel magát az egzisztenciális biztonságot, kiszámítható, megbecsült 
életpályát nyújtó középosztálybeli pozícióba. Igen egyenlőtlen küzdelem ez, amelyet a tanodáknak valamiképpen pacifikálniuk kell a megvalósulás egyeztetési folyamatai során. Az egyeztetési folyamatok azonban mindig a lokális viszonyok között történnek, ahol a rendszerlogika sajátos módokon érvényesíti erejét. Habár a munka tartalékserege nagyon is szükséges a tôke folyamatos felhalmozásához, a formális bérmunkán kívül rekedtek a helyi középosztály szempontjából mégis szó szerint „feleslegesnek” tűnhetnek, egyszerúen nemkívánatosnak, akiktől jobb lenne a falvaknak, városoknak megszabadulniuk, hiszen ők testesítik meg a strukturális labilitás és a társadalmi dezintegráció riasztó tapasztalatát. És mivel ez többnyire etnicizált népességet, esetünkben a cigányságot jelenti, a fenti kívánalmak olykor rasszista követelésként jelennek meg, máskor pedig helyi intézmények kirekesztő mechanizmusai által teljesülnek (vö. Feischmidt-Szombati 2013; Kovai 2017; Szalai 2007, 2010; Szombati 2018; Virág 2015).

Lokális szinten az osztályhelyzettel kapcsolatos aspirációk és félelmek tehát összekapcsolódnak az etnikai különbségtétellel, amely nagyban meghatározza a tanodák mozgástereit az egyeztetési folyamat során. Az aktoroknak a fenti státuszfélelmek kirekesztő mechanizmusai között kellene érvényesíteniük a hátrányos helyzetű, többnyire cigány gyermekek társadalmi mobilitását. Amint láttuk, az osztályhelyzet és az etnicitás összefonódása azonban rendszerszintủ folyamat, amely kiemelt szerepet játszik a lokális osztályviszonyok alakításában, egyenlőtlenségeinek újratermelődésében. Ugyanakkor a rendszerszintű folyamatok máshogy jelennek meg a különböző pozíciójú városokban, e különbségek pedig másfelé irányíthatják a tanodák egyeztetési folyamatait. Az általunk vizsgált városban a szélesebb, rendszerszintű folyamatok elsősorban a drasztikus népességcsökkenésben és az ezzel járó demográfiai átalakulásban mutatkoznak meg, amelyek maguk után vonják az osztályalapú etnikai különbségtétel változásait is.

\section{A megvalósulás helyszíne: osztály- és etnikai különbségek egy zsugorodó városban}

Az általunk vizsgált városban az osztályalapú etnikai különbségtétel a tartós népességcsökkenés és a demográfiai átrendeződés évtizedek óta zajló ambivalens folyamataiba illeszkedik (vö. Jelinek-Virág 2020; Virág 2020). Egy volt ipari középváros csak igen korlátozott mértékben teszi elérhetővé a magasabb státuszú osztálypozíciók elfoglalását, így a társadalmi mobilitás vágya elköltözésre sarkallja az arra képes rétegeket. A fenti folyamat legfőbb sajátossága tehát, hogy a városból való elvándorlás elsősorban a képzettebb, jobb pozíciójú lakosságra jellemző, míg a legkedvezőtlenebb helyzetű népesség erőforrás híján a városban ragad. Mivel a fenti osztályhelyzet sok esetben bizonyos etnikai hovatartozással társul, ezért a város osztályszerkezetét érintő demográfiai átalakulás együtt jár a cigányság arányának növekedésével is (vö. Durst 2010; Kovách 2012; Ladányi-Virág 2009; Virág 2010). Az osztályhelyzet etnicizálódása és a fenti demográfiai változások hatásai igen ellentmondásosak lehetnek (vö. Németh 2020). A jelenlegi munkaerőhiány következtében például olyan pozíciók is megnyílhatnak az etnikailag stigmatizált, marginalizált 
népesség számára, amelyek korábban nem, ami alapvetően kedvez a társadalmi mobilitás lehetőségeinek. Ugyanakkor a cigányság arányának növekedése újfajta kirekesztő mechanizmusokat indíthat el, hiszen a helyi középosztályi státusz védelme többek között a cigányságtól történő elzárkózásban manifesztálódik. A fentiek leginkább a városi oktatási rendszer szelekciós mechanizmusaiban érhetőek tetten, amely többnyire etnikai szegregációt is jelent (vö. Szalai 2010; Zolnay 2020). A tanodák szervesen kapcsolódnak a helyi oktatási rendszerhez, így elkerülhetetlen, hogy maguk is viszonyuljanak e szelekciós mechanizmusokhoz valamilyen módon, akár úgy, hogy részeivé válnak, akár a folyamatos ellenállás révén.

A városban tehát a társadalmi mobilitás évtizedek óta összekapcsolódik a térbeli mobilitással, pontosabban szólva a városból való elköltözéssel. Míg azonban a 2008-as válság előtt a megyén vagy országon belüli centrumok rendelkeztek nagyobb elszívó hatással, addig a válság után az EU-n belüli centrum-periféria viszony lett egyre hangsúlyosabb. A külföldi, elsősorban nyugat-európai munkavállalás a megélhetési stratégiák normatív mintázatává vált a városban a társadalom szinte összes rétegében (vö. Váradi 2019). A külföldi munkavállalás lehetővé teszi a helyi viszonyrendszerekből nem kinyerhető tőkék megszerzését, újfajta társadalmi mobilitási csatornát jelent, amely egyféle alternatív, sőt rivális társadalmi mobilitási útvonalként jelenik meg a tanodák oktatáson keresztül történő középosztályosodási projektje mellett. A külföldi munkavállalásnak a társadalmi mobilitásra és a tanodák működésére gyakorolt hatásairól még nincsen pontos képünk, annyi azonban biztosnak látszik, hogy a külföldi munkavállalás a fent leírt osztályalapú szelektív elvándorlás folyamataiba illeszkedik, hiszen a tartós kivándorlás a tőkeerősebb rétegeket érinti. A külföldi munkavállalás tehát tovább erősítheti a népességcsökkenés demográfiai átalakulással járó folyamatait, amelynek hatásai, mint láttuk, igen ambivalensek az osztályalapú etnikai különbségtétel múködésére.

A hátrányos helyzetű cigányság számarányának növekedése azonban nemcsak a fenti kirekesztő mechanizmusokat indíthatja el, hanem azt is eredményezheti, hogy a cigányság súlya megnő a helyi politikai közéletben, hiszen szavazataik jelentősége felértékelődik. A városban annak méretéhez és gazdasági-politikai súlyához képest egyébként is élénk roma közéletet találhatunk, mind civil, mind kisebbségpolitikai vonalon jelentős szereplők és intézmények nőttek ki az elmúlt évtizedekben. $\mathrm{E}$ szereplők különböző módokon és súllyal, de rendre helyet kapnak a város döntéshozatalában; ha szándékaikat nem is tudják érvényesíteni, a vezetés mégis legitim szereplőként tekint rájuk. Tanodáink szintén ezekhez az intézményekhez kapcsolódnak. Habár a demográfiai átalakulás fenti aspektusa konkrétan a kisebbségpolitikai érdekképviselet intézményéhez kötődő tanoda egyeztetési folyamataiban kap jelentőséget, általában a cigányság helyi pozíciójára is jelentős hatást gyakorol.

A tanodák egyeztetési folyamatai tehát a fenti strukturális körülmények között zajlanak, ezekben kell kezelniük valahogy azt a kulcsellentmondást, amely a középosztályosítási küldetés és a helyi viszonyok „strukturális realitása” között feszül. 


\section{A két tanoda: a „civil” és a „politikai”}

\section{Brókerek és közvetitők}

A civil és a kisebbségpolitikai intézményrendszer merőben más értelmezési keretet ad a tanoda programok megvalósulásának egyeztetési folyamataihoz. Az előbbi esetben a kulcsellentmondás explicit módon, problémaként jelenik meg a tanoda mindennapi müködésében. A program megvalósulását alapvetően határozza meg a feszültség az általa képviselt értelmiségi középosztálybeli habitus és a helyi társadalmi viszonyok reális lehetőségei között. A másik esetben ezzel szemben a kulcsellentmondás rendre feloldódik a célcsoport megélhetési stratégiái között. A tanoda mindennapi múködése során a célcsoport strukturális helyzetéből fakadó stratégiák azzal a veszéllyel fenyegetnek, hogy uralmuk alá hajtják a tanoda középosztályosodási projektjének eredeti küldetését. A fenti eltérés a civil és a kisebbségpolitikai intézményrendszer különbségeiből adódik, amelyekhez a két tanodát életre hívó helyi roma egyesületek kötődnek. E két intézményi környezet máshogyan kapcsolódik a szélesebb strukturális folyamatokhoz, más típusú viszonyt hoz létre a célcsoporttal és a többségi társadalommal, ahogyan más értékeket, erőforrásokat rendel a társadalmi mobilitáshoz is.

Egy kisváros társadalmi kontextusában azonban sokszor egy személyben súrüsödnek össze egy-egy hegemón diskurzus és intézményi kultúra osztályhabitushoz kapcsolódó értékvilágai. Gyakran e személyek lesznek ezek helyi képviselői, akik azonban nem csupán közvetítik a hegemón diskurzust, hanem a lokális viszonyokhoz adaptálva módosítják is azt, még akkor is, ha ezek a módosítások sok esetben elismerés hiányában láthatatlanok maradnak (Ivasuic 2018). Ők azok az aktorok, akiket a szakirodalom „brókernek” hív. A „bróker” az a szereplő, aki egyszerre müködik az erőforrások kapuőreként és áramoltatójaként, ugyanakkor a „bróker” nem pusztán közvetítő, hanem ő az, aki a közvetítés folyamatában kitermeli a hatalom és a morál helyi dinamikáit és értelmezését (Auyero 2000; Auyero-Benzecry 2017; James 2011; Koster - van Leynseele 2018).

A Kezdő Szikra és a Roma Hajnal egyesület alapítói ilyen szereplőknek tekinthetőek, hiszen ők azok, akik egy bizonyos értelemben hegemón intézményrendszer és diskurzus erőforrásait képesek a helyi közegbe becsatornázni. A Kezdő Szikra esetében ez az erőforrás a civil társadalom eszméjéhez és az értelmiségi osztályhabitushoz kötődő civil szervezeti hálózatot jelenti. Vezetője, Zsuzsanna e fenti civil intézményrendszer és diskurzus erőforrásait mozgósítja, viszi be egy volt iparváros lokális viszonyai közé. A városban az ő tevékenységeihez kötődnek az oktatáson keresztül történő roma középosztályosodás tipikus értékei. A Roma Hajnal esetében pedig az erőforrások a roma kisebbségi önkormányzat intézményrendszeréből és 
diskurzusából származnak, amelyek inkább a helyi politikai hatalomhoz kapcsolódnak. Az egyesület vezetője, Robin kapcsolati tőkéje révén egyfajta közvetítői szerepet tölt be a lokális intézményes (politikai) hatalom és a helyi szegénynegyed között. Robin az a közvetítő figura, aki a mindennapi létfenntartáshoz szükséges erőforrásokat csatornáz a helyi szegénynegyed közegébe. A következő fejezetekben a tanodák e két intézményrendszerhez kapcsolódó egyeztetési folyamatait mutatom be, amelyek szorosan kapcsolódnak alapítójuk életútjához és osztályhabitusához.

\section{A Kezdő Szikra: „elképzelt középosztály” egy volt iparvárosban}

\section{Egy gyárváros és az értelmiségi habitus}

A Kezdő Szikra egyesület több mint másfél évtizedes múködését alapvetően határozza meg a civiltársadalom ethoszának és az értelmiségi habitus helyének keresése a lokális társadalmi viszonyok között. A tanoda mindennapi múködésében szintén a civil társadalom ethoszával átitatott középosztályosítási projektje küzd az azt akadályozó strukturális folyamatokkal: többek között a civilszervezeti hálózatok leépülésével, a város strukturális helyzetéből fakadó erőforráshiányokkal, a helyi osztályalapú etnikai különbségtétel kirekesztő mechanizmusaival és végül, de nem utolsó sorban a célcsoport sérülékeny társadalmi helyzetéhez adaptálódó habitusával. E fenti értelmezési keret alakulása azonban nem magától értetődő, hanem a civil társadalom eszméjéhez kötődő intézményi hálózatból ered. Ebben a keretben a középosztályosodás nem pusztán az egzisztenciális biztonság elérését jelenti, hanem bizonyos értékek elsajátítását is, amelyek egyfajta értelmiségi habitushoz kapcsolódnak. Ilyen érték például az oktatás útján történő társadalmi mobilitás, az etnikai identitás egyéni döntésen alapuló választhatósága, a magaskultúra fogyasztása, szintén az oktatáshoz kötődő szakértelem elismerése vagy éppen a gyermekek egyéni készségeinek kiteljesítése. A Kezdő Szikra tanoda többek között ezeket az értékeket képviselve végzi tevékenységét egy olyan társadalmi közegben, ahol e fenti értelmiségi osztályhabitus megvalósulásának kevés a realitása, következésképpen a célcsoport társadalmi mobilitási stratégiái sem ebbe az irányba tartanak. Az egyeztetési folyamatok fő tétje tehát az ellentmondás kezelése a helyi társadalmi struktúra, a célcsoport reális lehetőségei és a tanoda által képviselt értékek között. Ahhoz azonban, hogy átlássuk a fentiek hatását a tanoda megvalósulásának folyamataira, érdemes megnéznünk a tanoda vezetőjének életpályáját, aki mint „bróker” figura közvetíti ezeket az értékeket, erőforrásokat a helyi közeg felé.

A Kezdő Szikra egyesület és tanoda alapítója, Zsuzsanna első generációs roma értelmiségi, most negyvenes éveinek elején jár, életpályája a helyi roma középosztályosodás egyik jellegzetes irányát mutatja meg, amelyben a civil szervezetek hajdani konjunktúrájának legalább akkora szerepe van, mint az oktatási rendszer mobilitási csatornáinak. Zsuzsanna, habár a városban nőtt fel, soha nem lakott az egykori ci- 
gánytelepen, ahol a népes oláhcigány közösség élt. Szemben a városi oláhcigány többséggel, ő romungró származású, szülei gyári munkások voltak, akik jellegzetes aszszimilációs életpályát futottak be. A szülők mindig arra törekedtek, hogy kapcsolati hálójuk a helyi cigány közösségen túlmutasson, lányukat pedig tanulásra ösztönözték, boldogulását elsősorban az oktatáson keresztül képzelték el. Zsuzsanna akkoriban a helyi gimnáziumban tanult tovább egyetlen romaként, azután pedig a közeli nagyváros tanítóképzőjén szerzett diplomát. Mindeközben Zsuzsannát más meghatározó impulzusok is érték. Még gimnazista korában ismerkedett meg a közeli nagyvárosban kibontakozó roma civil szerveződések munkájával. A főiskola alatt, majd annak elvégzése után is e civil szervezeteknél dolgozott, civil kapcsolathálókon keresztül bejáratos lett fővárosi, felső középosztálybeli értelmiségi körökbe is. Pályáját, értékválasztásait, felhalmozott kapcsolati és kulturális tőkéit ezek az élmények alakították. Amikor Zsuzsanna már úgy érezte, hogy elég tapasztalatot és szakmai gyakorlatot szerzett, elhatározta, hogy a városban hoz létre saját tanodát. Azzal a felvállalt céllal tette ezt, hogy a helyi hátrányos helyzetű gyerekekhez is eljuttathassa az értelmiségi, középosztálybeli habitus értékeit, amelyeket mobilitási pályája során ő is elsajátított.

Habár ez a fenti küldetés összhangban áll a tanodaprojektek küldetése által képviselt elvárásokkal, kevéssé kompatibilis a strukturális körülmények adta lehetőségekkel. A Kezdő Szikra tanoda megvalósulása ezért egy állandó helykeresésnek tekinthető a lokális társadalmi viszonyok között. E helykeresés tétje, hogy a tanoda megőrizze integritását és relatív autonómiáját a nála jóval dominánsabb helyi intézményi struktúrák, például az iskola és a szokásrendszerek, például a célcsoport stratégiái között, miközben a működés érdekében alkalmazkodnia is kell hozzájuk. A tanodának tehát egyfajta köztes teret kell létrehoznia az általa képviselt értékvilág és a volt gyárváros strukturális realitása között. Ez a köztesség a szakmai stáb közös értelmezési keretében „híd”-szerepként fogalmazódik meg.

\section{Tanoda mint „köztes tér”}

A tanoda mint „köztes tér” müködése többek között az iskola hegemón intézményével való viszonyában érthető meg. Az iskola intézménye dominanciájánál fogva mindig azzal a veszéllyel fenyeget, hogy a helyi oktatási rendszer szelekciós mechanizmusainak eszközévé teszi a tanodát, hiszen a tanoda a lokális kontextusban hamar a szegregált intézmények szerepébe kerülhet, ahová a „nem kívánatos” cigány gyermekek kerülnek. Hasonlóképpen az is állandó fenyegetésként jelenik meg, hogy az iskola teljesítményelvű logikája puszta „C” osztályos tanuló napközivé degradálja a tanoda igen komplex funkcióját. Az egyeztetési folyamatok során tehát a tanodának meg kell védenie magát az iskolák intézményi túlerejétől, mindezt úgy, hogy közben az együttmúködés is elengedhetetlen, hiszen a gyerekek egy része az iskola ajánlásával érkezik. $\mathrm{Az}$ iskolával történő egyeztetési folyamatok következésképpen igen egyenlőtlenek, a „köztes tér” könnyen elvesztheti kontúrjait. A tanoda autonómiájának megőrzésében 
a szakmai stáb közös értelmezési kerete döntő szerepet kap, hiszen úgy tűnik, részben ez biztosítja a tanoda integritását az azt szétszedő strukturális viszonyok között.

A Kezdő Szikra szakmai stábjának közös fejlesztői diskurzusában a gyermek társadalmi beágyazottságától, iskolai teljesítményétől függetlenül, önmagában álló értékként jelenik meg, mint egy kibontakozásra váró lehetőség, amely együtt jár a társadalmi felemelkedéssel. A tanoda mai gárdája: mentorok, különböző, diplomás szakemberek, közmunkások egyaránt osztják a Kezdő Szikra misszióját, vagyis azt, hogy a gyerekek az iskolai teljesítményük javulása mellett részesülhessenek a középosztálybeli gyerekeknek kijáró élményekben és értékekben. A stáb tagjai abban is egyetértenek, hogy a tanoda fő funkciója nem pusztán a jobban tanuló gyerekek „szállítása”, hanem egy olyan tér kialakítása, ahol a gyerek „önmaga” lehet, ahol felszabadulhat kicsit az iskola és a család vagy akár a kortárscsoport rá nehezedő elvárásaitól. A tanoda tehát egy olyan térként jelenik meg, ahol a strukturális kényszerek legalább pár röpke órára nem érvényesítik erejüket.

Ugyanakkor e „köztes tér” közös értelmezési keretének kialakulása, magának a szakmai stábnak a fenntartása sem független a strukturális lehetőségektől. Sőt az egyeztetési folyamat egyik legfőbb kihívása a tanodaprojektek által elvárt szakmai stáb biztosítása, hiszen a pályázatok még az inkább személyes készségeket igénylő mentori pozíció betöltését is diplomához kötik. A diplomával rendelkező szakemberek bevonása azonban extrém nehézséget jelent egy zsugorodó középvárosban, hiszen olyan, egyetemet végzett munkatársakra van szükség, akik nemcsak azonosulni tudnak a fenti küldetéssel, hanem személyes ambícióik, megélhetési stratégiáik szempontjából is megfelelő hely számukra egy középvárosi tanoda többnyire csak részfoglalkoztatást nyújtó pozíciójának betöltése. Habár Zsuzsanna rendkívül éles szemmel szúrja ki a kulturális tőkében és habitusban hozzá hasonló, szakértelemmel rendelkező embereket a városban, a fentebbi fejezetekben ismertetett mobilitási stratégiák igencsak leszúkítik számára a választékot.

A diplomás szakértelem biztosítása a hátrányos helyzetű gyermekek számára azonban a tanodának csak az egyik funkciója. A tanoda „köztes terének” fenntartásában talán még fontosabb az állandó jelenlétet, a tanoda hétköznapi múködését biztosító munkatársak alkalmazása, hiszen ők azok, akik a mindennapokban megteremtik a gyermekek számára a tanoda „köztes terének” biztonságát és otthonosságát. A tanodapályázatok azonban kevés forrást allokálnak erre a funkcióra, így e munkatársak megszerzése további egyeztetési folyamatokat igényel. Ezeket a munkaköröket olyan érettségizett, gyermekes, közfoglalkoztatott roma nők töltik be, akik úgy érzékelik, a helyi elsődleges munkaerőpiac jelenlegi körülményei között nem tudnák a munka és a család igényeit összeegyeztetni. Ők származásuk és személyes viszonyaik révén némileg kapcsolódnak a célcsoport társadalmi közegéhez, így a köztes téren belül is egyfajta közvetítőként múködhetnek a célcsoport és a tanoda társadalmi mobilitási projektje között. 
A „köztes tér” tulajdonképpen az „otthonlét” egy sajátos formája, ahol a különböző szereplők úgy ismerhetik fel a számukra otthonos viszonyokat, hogy közben valamilyen módon kapcsolódnak a tanoda középosztályosítási küldetéséhez. Ezt az „otthonosságot” elsősorban az informális viszonyok biztonsága teremti meg, amelyek főként Zsuzsanna köré összpontosulnak. A tanoda hétköznapi múködését szervező munkatársak az ő kapcsolati hálójából kerültek ki. A bizalomra épülő informális viszonyok nemcsak a közös értelmezési keret fenntartásában segítenek, hanem a bizonytalan strukturális helyzetben is kapaszkodót nyújtanak. Előfordult például, hogy Zsuzsanna nyugdíjas nagynénje akkor is bejárt „gazdasszonyként” dolgozni, amikor a finanszírozás éppen szünetelt, így biztosítva a tanoda múködésének folytonosságát. Az informális viszonyok azonban a célcsoport számára is elsődleges igazodási pontokat jelentenek, többnyire ezeken keresztül ismerik fel az otthonos motívumokat a tanoda „köztes terében”. $\mathrm{Az}$ informális kapcsolódások nélkül mindig fennáll a veszélye annak, hogy a tanoda funkciója felismerhetetlenné vagy értelmezhetetlenné válik a célcsoport számára.

\section{A tanoda mint „köztes tér” helye a célcsoport stratégiáiban}

A tanoda jelenleg egy háromemeletes bérház legfelső emeletén működik, félúton a szegénynegyed és a belváros között, ezzel is mintegy kifejezve köztes jellegét. A házba belépve már a lépcsőházban gyermekrajzok és színes feliratok fogadják a látogatót, amelyek mind-mind a „gyermek” mint kiteljesítendő érték elvét hirdetik: „értékes vagy”, „számít a véleményed”, „nagyszerű dolgokra vagy képes” - olvashatjuk, mintegy ellentételezve a gyermekek strukturális helyzetéből fakadó elhanyagoltságát. A tanoda maga egy olyan otthon képét idézi fel, ahol a biztonság mellett a kiteljesedéshez és a társadalmi felemelkedéshez szükséges kulturális javak is elérhetőek: számítógépek, könyvek, hangszerek, társasjátékok állnak a gyerekek rendelkezésére. A tanodába járó gyermekek sokszor csak bolyonganak e javak között, vagy egyiktől a másikig rohannak, felkapják, majd leteszik őket. A tanoda személyzete ilyenkor igyekszik „útba igazítani” őket, megtanítani az e javakhoz tartozó osztálypozíció viselkedési módjait. Az „útba igazítás” azonban más területeken is müködik, a tanoda a cigányság és az osztálypozíció viszonyát téríti el a megszokottól idegen irányba. A színes falakon Martin Luther King és Gandhi idézetei olvashatók, a szekrényeket lovári nyelvú szószedetek díszítik. A fentiek összekapcsolják az etnikai identitást az érdekérvényesítés és a középosztályosodás lehetőségével, ami újszerű a lokális kontextusban, hiszen a cigányság többnyire stigma, amely az alacsony osztálystátuszhoz társul.

Úgy tûnhet, a Kezdő Szikra tanoda a maga középosztályhoz kötődő értelmiségi habitusával egyfajta strukturális otthontalanságra lenne kárhoztatva a városban. A szülők és a tinédzserek egy része ennek megfelelően nem is találja meg a tanoda funkcióját. A tanoda egy értelmezhetetlen és így irreleváns tér számukra, vagy éppen az idegenséget ismerik fel benne, a középosztálybeli habitus intézményét, ahová ők életükben felhalmozott tapasztalataik alapján „nem valók”. A szülők és a gyerekek a tanodához is, mint minden, gyerekeket felügyelő intézményhez a hatósági jelleget társítják, elsősorban el- 
lenőrző funkcióval ruházzák fel, ami igencsak megnehezíti a bizalmi viszony kialakulását. Más esetekben a tanoda erősen stigmatizált hellyé válhat a célcsoport szemében, ahova „nyilvánvalóan” olyan gyerekek járnak, akikkel valami „gond” van, ezért igyekeznek elkerülni azt. A tanodának elsősorban a városban domináns mobilitási stratégiák között kell érvényesülnie, ami szintén számos kihívást hordoz.

Az egyik domináns mobilitási stratégia az oktatáshoz kötődik, amely elviekben kapcsolódik a tanoda középosztályosítási projektjéhez. A szülők azonban elsősorban a helyi oktatási rendszer szelekciós logikája szerint igyekeznek biztosítani gyermekeiknek az előbbre jutást. Ebben a logikában pedig minden intézmény kerülendő, ahol túl magas a hátrányos helyzetű cigány gyermekek aránya, következésképpen a tanoda is. A mobilitási stratégiák e fenti alaptételét még azok a szülők is elsajátítják, akiknek nincs elegendő erőforrásuk ahhoz, hogy gyermeküket magasabb státuszú intézménybe járassák. Esetükben e hegemón stratégia azt eredményezi, hogy „nem tudják” igénybe venni a tanoda szolgáltatásait, hiszen azt a helyi oktatási rendszer legalsóbb, stigmatizált szegmenséként értelmezik, ahonnan minden erejükkel próbálnak kikeveredni. A fentiek eredményeképpen az ún. feltörekvő családok egy része, akik még esetleg osztanák is a tanoda társadalmi mobilitáshoz kötött értékeit, nehezen vonhatók be.

A másik domináns társadalmi mobilitási stratégia, a külföldi munkavállalás kevéssé kapcsolódik az oktatáshoz. A külföldi munkavállalás egyféle alternatív, sőt rivális társadalmi mobilitási útvonalként jelenik meg a tanodák oktatáson keresztül történő középosztályosodási projektje mellett. E rivális stratégia erejét és hatásait a tanoda munkatársai is érzékelik, ezt többnyire úgy fogalmazzák meg, hogy a tanulásnak, főleg a diplomaszerzéshez szükséges érettséginek kisebb lett a presztízse az elmúlt években. „Ha egy gyereket ma megkérdezel, mi szeretne lenni, azt mondja, majd kimegyek németbe mosogatni” - mesélik. Mások olyan esetekről számolnak be, amikor a szülők drasztikus hirtelenséggel szakították meg gyermekük felfelé ívelő iskolai pályáját a külföldi munkavállalás miatt. A külföldi munkavállalás lehetősége a gyerekkel folytatott beszélgetésekben is megjelenik mint a jövőre vonatkozó ambíció. Ezt a stratégiát néhány külföldön keresett szakma kivételével többnyire nem kötik össze az oktatás útján történő felemelkedéssel.

A tanodának tehát a fenti két domináns mobilitási stratégia között kellene definiálnia a saját helyét, miközben mindkét stratégia dinamikái inkább a tanoda ellen hatnak, mintsem mellette. A megvalósulás egyeztetési folyamatai során azonban úgy tűnik, mégis létrejön a célcsoporttal a társadalmi mobilitás egyfajta közös értelmezési kerete, amely megteremti a kapcsolódás lehetőségét. Sok esetben azok a szülők és gyerekek veszik igénybe a tanoda szolgáltatásait, akik valamiképpen távol akarják magukat tartani strukturális helyzetüktől, például a szegénynegyed utcai életének fenyegetéseitől. "Amíg a gyerek tanodában van, addig sem lóg az utcán” - mondják a Kezdő Szikrába járó gyerekek szülei. A tanoda olyan tér a szülők és a gyerekek számára, ahol ha csak pillanatokra is, de kiléphetnek abból a strukturális pozícióból, amelyben életük nagy részét töltik. A tanodának az a felvállalt funkciója, 
hogy a gyermek a tanoda köztes terében megpihenjen kicsit a ránehezedő strukturális kényszerek között, tehát úgy tűnik, sok esetben rímel a célcsoport igényeire.

A fenti egyeztetési folyamatok azonban rendre strukturális korlátokba ütköznek a megvalósulás során. A sérülékeny strukturális helyzetû́ családokban például a gyerek nem kifejezetten a kibontakozásra váró lehetőség, hanem inkább egy funkció, többek között például munkaerő. A nagyobb testvéreket sokszor a kisebbek felügyeletére fogják be, így a tanodában töltött időre ez a segítség kiesne a család életéből. A tanoda és a célcsoport különböző, gyermekkel kapcsolatos attitűdje sokszor teljesen megakasztja az egyeztetési folyamatokat, nem egy lánygyermek esett ki a tanodából a fentiek miatt. Ugyanakkor a tanoda legfóbb vonzereje az, hogy a sérülékeny strukturális helyzetből fakadó hiányokat pótolni tudja, tehát egyfajta kvázi „szociális intézményként” működik. A legkülönfélébb hiányok lehetnek ezek, a pótvizsgára felkészítő magántanártól kezdve a nyári táboron át a délutáni uzsonnáig. A tanoda e hiánypótló funkciója azonban a szégyennel is társítja az intézményt, olyan hellyé teheti a célcsoport szemében, ahová azok mennek, akik nem tudják biztosítani e dolgokat a gyermekeiknek, tehát a tanoda a szegénységgel járó stigmatizáció terévé válhat.

Az egyeztetési folyamatoknak tehát számos strukturális kényszerítő tényezőn kell valahogyan úrrá lennie, legyenek azok a társadalmi mobilitás hegemón stratégiái, az etnikai különbségtétel kirekesztő mechanizmusai vagy éppen a tanoda „strukturális otthontalansága”, „középosztályiságának” idegensége a célcsoport szemében. Azt is láttuk, hogy az egyeztetési folyamatok során létrejönnek kapcsolódási pontok, kialakul egy közös értelmezési keret, amelyben a tanoda értékkel ruházódik fel, a mindennapok során hasznosítható intézménnyé válik a célcsoport bizonyos tagjai számára. Ugyanakkor fontos megjegyezni, hogy mind a strukturális korlátok leküzdésében, mind a kapcsolódási pontok megtalálásában kiemelt szerepet játszanak az informális viszonyok, a személyes kötődések. Szinte kivétel nélkül minden szülő egyfajta személyes élményt nevez meg a tanodával való bizalmi viszony első lépéseként, legfőképpen Zsuzsannával, aki minden erejével igyekszik elhozni a volt gyárváros lakóinak a középosztálybeli értelmiségi habitus értékeit és erőforrásait.

Mint láttuk, a Kezdő Szikra egyeztetési folyamatainak fő tétje, hogy valamiképpen kezelje az ellentmondást az értelmiségi habitushoz kötődő középosztályosodás egyéni projektje és a strukturális kényszerek között, amelyek a célcsoport osztályhelyzetét és mobilitási stratégiáit alakítják. Az egyeztetési folyamatok során létrejönnek a találkozási pontok a tanoda küldetése és a célcsoport stratégiái között. Ugyanakkor a tanoda köztes terének integritását folyamatosan kihívás elé állítják a zsugorodó, volt gyárváros társadalmi viszonyai, köztük a pár éve létesült új tanoda, a Roma Hajnal eltérő intézményi logikára támaszkodó múködése.

\section{A Roma Hajnal: a „strukturális realitás”}




\section{Politikai klientelizmus és roma érdekképviselet}

A Roma Hajnal egyesület a kisebbségpolitikai érdekképviselet intézményi világához kapcsolódik. Ebben az intézményi keretben az ún. „strukturális realitás” nem akadály, hanem egyszerűen az a terep, ahol az erőforrásokért küzdeni kell. Ennek megfelelően a kulcsellentmondás a középosztályosítási projekt és a „strukturális realitás” között nem feszültségként jelenik meg, mint a Kezdő Szikra esetében. A Roma Hajnalnál éppen az a veszély fenyeget, hogy a tanoda szinte teljességgel illeszkedik a helyi társadalmi viszonyok dinamikáihoz, ez a különös harmónia pedig majd a középosztályosítási projekt eltűnéséhez vezet. A fenti különbség a Kezdő Szikrához képest elsősorban a különböző intézményi és diszkurzív háttérból fakad, amelyekbe a tanodák ágyazódnak.

A Roma Hajnal egyesület a 90-es években induló roma kisebbségi politika intézményi hátteréből nőtt ki, amelyben az érdekképviselet, valamint a társadalmi felemelkedés kevéssé a civil társadalom eszméjéhez vagy az oktatáshoz kapcsolódik, inkább a helyi és országos politikai viszonyokhoz kötődik. Az érdekképviseletnek és a társadalmi felemelkedésnek ez a stratégiája a szegény közösségekre jellemző politikai klientelizmus gyakorlatait hozza létre (Auyero 2000: 55-81; Auyero-Benzecry 2017: 99-119). A roma érdekképviselet politikai intézményéhez kapcsolódó Roma Hajnal egyesület a politikai klientelizmus szálain keresztül szorosan be van kötve a helyi társadalom strukturális viszonyaiba, ám úgy tünik e viszonyok is csak szűk teret adnak egy tanoda fejlesztôi tevékenységének. A Roma Hajnal tanoda esetében az egyeztetési folyamatok tétje éppen az, hogy a policy eredeti középosztályosítási projektje ne tủnjön el teljesen a célcsoport strukturális helyzetéből fakadó stratégiái között, a közös értelmezési keretben pedig valamiképpen helyet kapjon a középosztályosítási projekt relevanciája.

Ahhoz azonban, hogy a Roma Hajnal tanoda múködését és társadalmi beágyazottságát jobban átlássuk, szintén érdemes megismerni alapítójának, jelenlegi vezetőjének életpályáját, hiszen abban nyomon követhető a roma kisebbség politikai érdekképviseletének és a helyi cigány közegeknek a viszonya, ahonnan az egyesület alapítója is származik. Robin, ahogy a városban szólítják, negyvenes éveinek elején járó roma férfi. Életpályája egy darabig párhuzamosan haladt a városi cigányság társadalomtörténetével, családja a helyi oláhcigány közösséghez tartozott. Robin kora gyermekkorát a városszéli cigánytelepen töltötte, szülei és idősebb testvérei a gyárban dolgoztak, az iskola után az ő útja is egyenesen a gyárba vezetett, amely akkoriban a boldogulás evidens helyszíne volt a helyi cigányság számára. Zsuzsanna szüleivel ellentétben Robin apja és anyja a felemelkedés lehetőségét nem annyira az oktatásban és az etnikai határokon túlmutató kapcsolati tőkében, hanem éppen a cigánysághoz kapcsolódó rokoni hálózatok erejében látta. Fiaik később e hálózatok múködtetésével értek el sikereket a helyi roma politika világában. A 90-es években Robin szintén a rokoni szálakon keresztül, testvérei révén került kapcsolatba az akkoriban kibontakozó roma kisebbségi önkormányzatiság intézményével. A roma érdekvédelem kérdése azonban a gyár bezárása után erősen összefonódott a saját önfenntartás egzisztenciális tétjeivel. A gyár bezárása ugyanis Robint és családját is 
érzékenyen érintette, a „politika” pedig egyfajta mobilitási pályát jelentett a Robinhoz hasonló, munka nélkül maradt roma fiatalemberek számára, olyan intézményt, amelyen keresztül jól jövedelmező kapcsolatokra lehet szert tenni.

A 2000-es évekre Robin és testvérei, valamint a velük politikai szövetségben állók megszervezték a megyei roma önkormányzatokat, ahol Robin jelenleg is vezető szerepet tölt be. Robin és testvérei a 90-es évek végétől a helyi önkormányzat munkájában is rész vesznek különböző pozíciókban. Robin a jelenlegi vezetéssel is igen szoros kapcsolatot ápol, nyílt támogatója a polgármesternek. Ő és testvérei azonban azt is hangsúlyozzák, hogy mind az érdekképviselet, mind a fenti kapcsolati tőke kamatoztatása csakis a megfelelő számú szavazat biztosításával lehetséges, hiszen a helyi roma vezetők csak így kerülhetnek alkupozícióba a városi politikai döntéshozatalban. A szavazatok biztosítása viszont, ahogy a kisebbségi önkormányzati pozíció megtartása is, a helyi marginalizált roma közösségben való jártasságot, állandó jelenlétet igényel. Ezt az állandó jelenlétet a Roma Hajnal egyesület biztosítja, amely Robin vezetésével a város szegénynegyedében múködik, és amelynek tevékenységi körébe a tanoda is beletartozik.

A Roma Hajnal egyesület múködése nagyon hasonló ahhoz, amit Auyero és Benzecry ír a politikai klientelizmus múködéséről Buenos Aires szegénynegyedében (Auyero 2000: 55-81; Auyero-Benzecry 2017: 99-119). Az egyesület a tanodán kívül is igen szerteágazó tevékenységeket folytat, úgymint adományosztást, különböző felnőttképzések, roma napok szervezését, cigány népzene klubot gyermekeknek, számtalan egyéni segítségnyújtást. Az egyesület szerteágazó tevékenységei erőforrásokat csatornáznak be egy rendkívül erőforráshiányos közegbe, mégpedig Robin kapcsolathálóján keresztül, amelyet a helyi hatalommal alakított ki. „Majd beszélek Robinnal” - szokták mondani helyben, ha valakinek olyan segítségre van szüksége, amelyet a helyi hatalom tudna nekik biztosítani (pl. közmunka, rendkívüli segély, szociális bérlakás). Ugyanakkor a segítségért folyamodók mind tudni vélik, hogy Robin mit kér ezért cserébe: annak a pozíciónak a megerősítését, ahonnan ő ezekhez az erőforrásokhoz hozzáfér, vagyis a szavazatukat. Az egyesület Robin kapcsolati tőkéje révén egyfajta közvetítői szint szerepét tölti be az intézményes hatalom és a helyi közeg között, Robin pedig az a közvetítő figura, akit a szakirodalom „brókernek” hív (Auyero 2000; Auyero-Benzecry 2017; James 2011; Koster - van Leynseele 2018).

A tanoda tehát a politikai klientelizmus fenti dinamikáiba ágyazódik bele, a lakók sok esetben nem is igazán választják el az egyesület és Robin egyéb tevékenységétől, ennek megfelelően is viszonyulnak hozzá. Míg a Kezdő Szikrát a fent leírt strukturális otthontalanság jellemzi, addig a Roma Hajnal tanodáját éppen ellenkezőleg, a helyben uralkodó strukturális viszonyok hálózzák be, múködését azok fenyegetik. Robin tevékenységéhez a lakók, a „célcsoport” viszonya igen ambivalens. Egyfelől a segítségkérés és az erőforrásokhoz való hozzáférés egyik legkézenfekvőbb eszköze, hiszen úgy túnik, az általunk vizsgált közegekre is igaz az, amit Auyero ír a politikai klientelizmusról és a bróker figurájáról. Vagyis hogy ezekben a köze- 
gekben a politika nem kollektív harc az államhatalomért, nem is piszkos üzlet, hanem segítő és hasznos gyakorlat, potenciális hozzáférés az állami erőforrásokhoz az önkormányzat közvetítésével. A bróker szintén nem a kollektív érdek és akarat képviselője, nem is önző, korrupt figura, hanem egy többé-kevésbé hatékony problémamegoldó (Auyero: 2000: 55-81; Auyero-Benzecry 2017: 99-119). Másfelől a mi közegeinkben e fenti gyakorlatnak megvan a maga kritikája, ami részben annak is köszönhető, hogy Robin klientúrája nem állandó, nem csak bizonyos embereken segít, hanem bizonyos helyzetekbe kerülő embereken. Mikor az adott helyzet elmúlik, a lojalitás is csökkenhet. A fő kritika e gyakorlattal szemben az, hogy Robin pusztán saját érdekei szerint használja az embereket, még a gyerekeket is, így a tanoda tevékenysége szintén a klientelizmus értelmezési keretébe kerül. Ha pedig ez megtörténik, a tanoda veszélyes hellyé válhat a célcsoport szemében, amely a gyermeken keresztül erősíti a klientalizmus függő viszonyát a szülők és Robin között. Az egyeztetési folyamatok egyik fő tétje, hogy a klientelizmus fenti logikája ne uralja teljesen a célcsoporttal közös értelmezési keretet.

\section{Tanoda a szegénynegyed kontextusában}

A Roma Hajnal tanoda tehát többnyire a klientelizmus fenti keretében értelmeződik a helyi közeg számára, tevékenységét az azzal kapcsolatos folyamatos bizalmatlanság kíséri. A tanoda a szülők és a gyerekek szemében nem válik el attól a társadalmi színtértől és strukturális helyzettől, amelyben élnek, így akik ilyen térre vágynak, inkább a másik tanodába viszik a gyermekeiket. A Kezdő Szikra térben is egyfajta köztességet képvisel, a gyerekeknek át kell lépni bizonyos határokat, eljönni a környékről, belépni egy csendes bérházba, bekopogni egy ajtón, ahol ismeretlen arcok fogadhatják őket. Ezzel szemben a Roma Hajnal része a szegénynegyed mentális térképének, Robint mindenki ismeri, ahogy tudni vélik különböző ügyeinek szövevényes érdekeltségeit is.

Míg a Kezdő Szikra esetében az osztályhelyzethez kötődő habituális távolság jelenti a kihívást a célcsoport számára, addig a Roma Hajnalnak a közös társadalmi gyakorlatok túlzott közelségével kell megbirkóznia ahhoz, hogy a tanoda stabil gyerekgárdával müködhessen. A Roma Hajnalba leginkább azok a gyerekek jutnak el, akik szüleinek Robinhoz fűződő kapcsolata éppen a klientelizmus egy bizalomteli szakaszában van, vagy viszonyukat például valamely rokoni szál miatt egyébként is a bizalom jellemzi. Ők azonban azonnal továbbállnak, ha szüleik és Robin viszonyában negatív változás áll be. Márpedig a klientelizmus viszonyainak legfőbb jellemzője, hogy az adott érdekeknek megfelelően hullámzik a feltétlen lojalitás és a teljes bizalmatlanság között, hiszen a lakók Robin segítségét függésként is értelmezik. Tehát ha az egyeztetési folyamatok a klientelizmus értelmezési keretében zajlanak, akkor ugyan könnyen bevonhatóak a gyerekek, de ugyanolyan könnyen el is veszíthetőek. Ebben az értelmezési keretben a tanoda középosztályosítási projektje elveszti a hitelességét a célcsoport szemében. 
Ugyanakkor a Roma Hajnal tanodának nemcsak a klientalizmus gyakorlataival kell összeegyeztetnie a tevékenységét, hanem a szülők gyermekük védelmére vonatkozó stratégiáival is, amelyek elsősorban a szegénynegyed utcai életének kontrollálásában mutatkoznak meg. Az utcai élet dinamikájának egyik fő mozgatórugója a gyerekek védelme és fenyegetettsége. A házak előtti padokon, lépcsőkön fiatal aszszonyok, nagymamák ücsörögnek. Kint létük funkciója, hogy igyekeznek lehatárolni és irányítani gyerekeik útjait, megóvni őket például a drogosok látványától vagy más, gyermekét hasonló vehemenciával védelmező szülőtől. Sokan inkább azt a megoldást választják, hogy nem engedik a környéken csatangolni a gyermekeiket. Az utca a stigmatizált, sérülékeny strukturális helyzet szimbolikus helyszíne, így az utcai élet elkerülése és a gyermekek mozgásának kontrollálása a társadalmi mobilitásra vonatkozó aspirációk egyik legfőbb aktusa lesz. Más, stigmatizált szegénynegyedhez hasonlóan e védelem itt is a végtelenségig fragmentálja a teret (Wacquant 2008.) Mindenkinek megvan az a határ, amelyen túl már nem megy, vagy amelyen túlra már nem engedi a gyerekét, legalábbis elviekben. A Roma Hajnal könnyen abba a régióba eshet, amelytől éppen a szülők óvják gyermeküket. A Roma Hajnal sokak szemében eleve a szegénynegyed stigmatizált teréhez tartozik, ezért alkalmatlannak tűnik a társadalmi mobilitás elősegítésére. Más esetekben a fragmentáció egyéb dinamikái teszik kerülendő hellyé a tanodát, például amikor a szülő úgy véli, éppen azok a gyermekek járnak oda, akiktől ő a sajátját távol tartaná.

A Roma Hajnal tanodába nemcsak azok a gyermekek jutnak el, akiknek szülei éppen bizalomteli kapcsolatban állnak Robinnal, hanem azok is, akiknek útjait szüleik valamely okból kifolyólag kevésbé tudják a fenti módon kontrollálni. Ők azok, akik saját sérülékeny strukturális helyzetük szűk köreit járják, délelőttjüket a legalacsonyabb presztízsű iskola szegregált osztályában töltik, délután pedig a szegénynegyed utcáin bandáznak. Ők könnyen elkeverednek a Roma Hajnal helyiségébe, hogy ott éljék tovább társasági életüket. Szemükben Robin egy nagyon is ismerős tekintélyszemély, egyfajta nagybácsi- vagy apafigura, aki része a számukra otthonos viszonyrendszereknek. A Roma Hajnalba érkezve a gyerekek megtárgyalják Robinnal saját kis közegük aktuális ügyeit, azt, hogy ki kibe szerelmes, ki kivel szökött meg, és mindezt a szegény cigány közösségekre jellemző beszédmódban teszik, ugratásokkal fűszerezve (vö. Réger 1999). A már tizenéves fiúk szemében Robin nemcsak egy, a saját közegükhöz kötődő sikeres férfi, hanem egy olyan figura is, aki mögé beállva az erőforrásokhoz való hozzáférésre számítanak, még ha sok esetben ez csupán Robin pozíciójához kapcsolódó fantázia is. A Roma Hajnal törzsközönsége tehát nem elsősorban a tanuláson és a középosztályosodási aspirációkon keresztül kapcsolódik a tanoda tevékenységéhez, őket elsősorban a tanoda közösségi programjai vonzzák, a főzőklubok, a közös focik, de legfőképpen az egyesület keretében müködő „hagyományőrző klub”, vagyis a cigánynépzene- és táncoktatás. A „hagyományőrző klub” egyféle „alacsony belépési” küszöböt jelent, amely azoknak a gyerekeknek könnyú átlépni, akiknek a tanoda és minden más, oktatással kapcsolatos intézmény inkább szorongást okoz. 
Ugyanakkor az ismerős közeg, amilyen könnyen behúzhatja a gyerekeket az egyesület és a tanoda tevékenységeibe, éppen ezen ismerősség okán ugyanolyan könnyen ki is pöröghetnek onnan. Nem pusztán a klientelizmus fenti gyakorlatai miatt történhet ez meg, hanem azért is, mert a gyerekek számára a Roma Hajnal illeszkedik a szegénynegyed életének dinamikáiba, elég egy sértődés, egy kisebb konfliktus, egy szerelmi ügy, vagy ha éppen az utcai élet dinamikái jobban lekötik őket, máris hetekre, hónapokra felszívódhatnak. A fentiek olyan közös érdekeken alapuló egyezségekkel lesznek elkerülhetőek, amelyek nem a középosztályosodási projekthez kapcsolódnak, hiszen az a gyermekek számára nem értelmezhető perspektíva. A gyerekek érdekeltsége származhat a szülők és Robin között fennálló, korábban leírt viszonyból, de a tanodába járás lehet a feltétele a nyári táboroknak vagy a népzenei csoportban való részvételnek. Az egyeztetési folyamatok többnyire rövid távú, átlátható és megfogható érdekek mentén zajlanak, hiszen a középosztályosodás időtávja beláthatatlan. Az egyeztetési folyamatok során a tanoda nem tud leválni a szegénynegyed közegének stratégiáiról és mindennapi életéről, sőt a közös értelmezési keret is ezen belül jön létre, enélkül azonban a tanoda középosztályosítási projektje eltűnhet a szegénynegyed mindennapi életének dinamikái között.

\section{Összefoglalás}

Tanulmányomban egy zsugorodó, volt ipari középváros két tanodáján keresztül vizsgáltam, hogy a tanodák fejlesztői tevékenységének megvalósulására hogyan hatnak a lokális és szélesebb strukturális folyamatok. A két vizsgált tanoda két különböző, a hátrányos helyzetú roma közösségekhez kapcsolódó intézményrendszerhez és diszkurzív kerethez kötődik. Az egyik tanoda a 90-es években induló civil szervezetek konjunktúrájához kapcsolódik, a civil társadalom eszméjéhez és az értelmiségi habitushoz köti a középosztályosodási törekvéseket. A másik szintén a 90-es években induló roma kisebbségi politika intézményi világához kötődik, amelyben az érdekképviselet csak a pártpolitika logikáján és erőterén belül képzelhető el. Tanulmányomban abból indultam ki, hogy az az intézményi és diszkurzív háttér, amelyhez a tanodák kötődnek, nagyban befolyásolja a programok megvalósulásának módjait.

A tanulmányban a nemzetközi fejlesztéseket vizsgáló kritikai irodalom eredményeit használtam, amelyek szerint egyrészt a fejlesztői tevékenységek maguk is részei azoknak az egyenlőtlenségeket termelő folyamatoknak, amelyek a fejlesztendők sérülékeny strukturális helyzetét meghatározzák. Másrészt azt az állítást követtem, hogy a fejlesztések „sikere” nem pusztán a policy megvalósulását jelenti és nem is a policy függvénye, hanem a megvalósulás során létrejövő egyeztetési folyamatoké, amelyek a programok különböző szereplői (a fejlesztők és a célcsoport) között zajlanak. A fejlesztők csak úgy tudnak hatást gyakorolni, ha a javaslataik, elképzeléseik lefordíthatóak az érintettek vagy bármely résztvevő saját szándékaira, céljaira, ambícióira. A fenti megállapításokat használva a tanulmányomban azt vizs- 
gáltam, hogyan zajlik ez az egyeztetési folyamat a tanodák esetében, hogyan lesznek összehangolhatóak a különböző résztvevők érdekei, értékei és ambíciói, valamint hogy ezeket hogyan alakítja a tanodák fenti intézményi háttere. Az egyeztetési folyamat fő kihívása a tanodák esetében a tanodaprogramok eredeti célkitűzése, vagyis a középosztályosítási projekt megvalósítása egyéni erőfeszítéseken keresztül, valamint a "strukturális realitás", vagyis a célcsoportot előnytelen pozícióban tartó gazdasági, politikai folyamatok között feszülő ellentmondás kezelése.

A tanulmány ugyanakkor abból indult ki, hogy az egyeztetési folyamatokat mindig az adott strukturális kontextusban uralkodó viszonyrendszerek alakítják, ami esetünkben egyrészt egy zsugorodó, volt iparváros strukturális körülményeit, másrészt az osztályhelyzettel összefüggő cigány-magyar különbségtétel múködését jelentik. Az általunk vizsgált városban a szélesebb, rendszerszintű folyamatok elsősorban a drasztikus népességcsökkenésben és az ezzel járó demográfiai átalakulásban mutatkoznak meg, amelyek a hátrányos helyzetủ roma lakosság arányának növekedésével járnak. Ez a demográfiai átalakulás ellentmondásosan hat az osztályalapú etnikai különbségtétel múködésére, hiszen egyszerre nyitja meg a társadalmi felemelkedés útjait, termel ki új kirekesztő mechanizmusokat és növeli meg a cigány lakosság politikai jelentőségét a helyi közéletben. A fentiek eltérő módokon jelennek meg a két különböző intézményrendszerhez kapcsolódó tanoda egyeztetési folyamataiban. Ezek az intézmények ugyanis máshogyan kapcsolódnak a helyben lejátszódó strukturális folyamatokhoz, valamint más értékeket, erőforrásokat rendelnek a társadalmi mobilitáshoz, ennek megfelelően az egyeztetési folyamatok is eltérő tétekkel zajlanak.

A civil társadalom eszméjéhez kapcsolódó, inkább értelmiségi, középosztálybeli értékeket közvetítő tanodát egyfajta „strukturális otthontalanság” jellemzi, ami azt jelenti, hogy a közvetítendő habitus csak kevés ponton érintkezik egy hátrányos helyzetǔ, volt ipari középváros strukturális viszonyaival. Ebben az esetben az egyeztetési folyamatok fő tétje a fenti ellentmondás feloldása, a találkozási pontok megtalálása a célcsoporttal. A roma érdekképviselet politikai intézményéhez kapcsolódó tanoda ezzel szemben a politikai klientelizmus szálain keresztül nagyon szorosan be van kötve a helyi társadalom strukturális viszonyaiba és a szegény roma közösség életébe. Ebben az esetben azonban éppen ez a szoros strukturális beágyazottság jelenti az egyeztetési folyamatok fő kihívását, hiszen ha a tanoda a politikai klientelizmus értelmezési keretébe kerül a célcsoport számára, akkor a tanoda középosztályosítási projektje végleg elveszti hitelességét. A tanulmányban a két tanoda esetén keresztül mutattam be, hogy a tanoda fejlesztői tevékenysége az egyeztetési folyamatok során kénytelen kezelni az ellentmondást a programok célja és a „strukturális realitás” között ahhoz, hogy egyáltalán megvalósulhasson. Ugyanakkor az egyeztetési folyamatokat mindig az adott intézményi és diszkurzív háttér irányítja, amelybe ágyazódva a tanodák múködnek, és amelyeken keresztül a szélesebb strukturális folyamatokhoz kapcsolódnak. 


\begin{abstract}
The paper explores how Hungarian After School Support Programs (ASSPs) supporting the social mobility of underprivileged Roma children operate in the social context of a shrinking city. The article uses one of the main axioms of critical development studies stating that the realization of developmental projects is a result of a continuous negotiation process between the project's staff and the target group. The paper presents two types of negotiation processes through two ASSPs of a postindustrial middle town. The main challenge of such negotiation processes is to resolve a contradiction: namely, that the mission of Roma children's social mobility primarily concentrating on individual life trajectories are impeded by such structural obstacles (broader economic, political processes) that ASSP-s don't have resources to deal with. The paper explores how the treatment of this contradiction shapes the everyday functioning of ASSPs in the social context of a shrinking city.
\end{abstract}

Keywords: development activities, social mobility, ethnic distinction, shrinking cities

\title{
Irodalom
}

Annist, A. (2005): The Worshippers of Rules? Defining Right and Wrong in Local Participatory Project Applications in South-Eastern Estonia. In Mosse, D. - Lewis, D. (eds.): Aid effect: Giving and Governing in the International Development. London: Pluto Press, 150-170.

Auyero, J. (2000): The Logic of Clientelism in Argentina: An Ethnographic Account. Latin American Research Review, 35(3): 55-81.

Auyero, J. - Benzecry, C. (2017): The Practical Logic of Political Domination. Conceptualizing the Clientelist Habitus. Sociological Theory, 35(3): 179-199.

Baráth Sz. (2016): Integráció és tanoda. In Fejes J. B. - Lencse M. - Szúcs N. (szerk.): Mire jó a tanoda? Szeged: Motiváció Oktatási Egyesület, 180-183.

Boatcă, M. (2015): World-Systems Analysis and the Feminist Subsistence Perspective. In uô: Global Inequalities Beyond the Occidentalism. Farnham/Burlington: Ashgate Publishing Company, 121-138.

Dunaway, W. A. (2018 [2012]): Félproletár háztartás a modern világrendszer longue durée-je folyamán. Fordulat, 24: 53-88.

Durst J. (2010): „Minden évben máshogy fordul a világ”. Anblokk, 4: 34-38.

Efremova, G. (2012): Integralist Narratives and Redemptive Anti-Gypsy Politics in Bulgaria. In Stewart, M. (ed.): The Gypsy "Menace": Populism and the New AntiGypsy Politics. London: Hurst and Company, 43-66.

Elyachar, J. (2005): Market of Dispossession: NGO, Economic Development and the State in Cairo. London: Duke University Press.

Escobar, A. (1995): Encountering Development: Making and Unmaking the Third World. Princeton: Princeton University Press.

Feischmidt M. - Szombati K. (2013): Cigányellenesség és szélsőjobboldali politika a magyar társadalomban: Gyöngyöspata és a hozzá vezető út. Esély, 24(1): 74-100. 
Fejes J. B. (2016): Szegregál-e a tanoda? In Fejes J. B. - Lencse M. - Szúcs N. (szerk.): Mire jó a tanoda? Szeged: Motiváció Oktatási Egyesület, 171-179.

Ferguson, J. (1994): The Anti-Politics Machine: „Development”, Depoliticization and Bureaucratic Power in Lesotho. Minneapolis: University of Minesota Press.

Ferguson, J. (2015): Give a Man a Fish: Reflection on the New Politics of Distribution. Durham: Duke University Press.

Grill, J. (2018): „Re-learning to labour? 'Activation Works' and newpolitics of social assistance in the case of Slovak Roma". Journal of Royal Anthropological Institute, 24(1): 105-119.

Ivasuic, A. (2018): Alter-narratives: Seeing Ordinary Agency. In Ivasuic, A. - Beck, S. (eds.): Roma Activism. Reimagining Power and Knowledge. New York - Oxford: Berghahn Books, 129-153.

James, D. (2011): The Return of the Broker: Consensus, Hierarchy, and Choice in South African Land Reform. Journal of the Royal Anthropological Institute, 17(2): 318-338.

Jelinek Cs. - Virág T. (2020): Zsugorodó városok és társadalmi egyenlőtlenségek Magyarországon. Szociológiai Szemle, 30(2): 4-26.

Kende Á. (2018): A roma gyerekek méltányos oktatását segítő programok lehetőségei az oktatási egyenlőtlenségek rendszerében. socio.hu, 8(1): 144-162.

Koster, M. - van Leynseele, Y. (2018): Brokers as Assemblers: Studying Development Through the Lens of Brokerage. Ethnos. Journal of Anthropology, 83(5): 803-813.

Kovách I. (2012): A vidék az ezredfordulón. A jelenkori magyar vidéki társadalom szerkezet és hatalmi változásai. Budapest: Argumentum Kiadó.

Kovai C. (2017): A cigány-magyar különbségtétel és a rokonság. Budapest: L'Harmattan.

L. Ritoók N. (2016) Tanoda vagy iskola? In Fejes J. B. - Lencse Máté - Szŭcs N. (szerk.): Mire jó a tanoda? Szeged: Motiváció Oktatási Egyesület.

Ladányi J. - Virág T. (2009): A szociális és etnikai alapú lakóhelyi szegregáció változó formái Magyarországon a piacgazdaság átmenet időszakában. Kritika, 7-8: 2-8.

Van der Linden, M. (2001): Global Labor History and "the Modern World-System": Thoughts at the Twenty-Fifth Anniversary of the Fernand Braudel Center. International Review of Social History, 46(3): 423-459.

Mitchell, T. (2002): Rule of Experts: Egypt, Techno-Politics, Modernity. Los Angeles: University of California Press.

Mosse, D. (2005): Cultivating Development: An Ethnography of Aid Policy and Practice. London: Pluto Press.

Németh K. (2015): A terepmunka és a kutatói pozíció reflektálása mint az értelmezés rejtett erőforrása. In Virág T. (szerk.): Törésvonalak: szegénység és etnicitás vidéki terekben. Budapest: Argumentum, 27-44.

Németh K. (2017): Beszédes hallgatás: A csend interpretálása és a megismerés dilemmái a társadalomtudományi kutatásban. Szociológiai Szemle, 27(2): 4-22. 
Németh K. (2020): Marginalizált térből átmeneti térbe: egy térbeli-társadalmi mobilitási pálya megélt jelentései. Szociológiai Szemle, 30(2): 50-71.

Petrovici, N. - Raț, C. - Simionca, A. - Vincze, E. (2019): Introduction: Racialized Labour of Dispossessed as an Endemic Feature of Capitalism. In Vincze, E. Petrovici, N. - Raț, C. - Picker, G. (eds.): Racialized Labour in Romania: Spaces of Marginality at the Periphery of Global Capitalism. London: Palgrave MacMillan, $1-37$.

Quijano, A. (2000): Coloniality of Power and Eurocentrism in Latin America. In: International Sociology, 15(2): 215-232.

Rajaram, P. K. (2018): Refugees as Surplus Population: Race, Migration and Capitalist Value Regimes. New Political Economy, 23(5): 627-639.

Réger Z. (1999): Teasing in Linguistic Socialization of Gypsy Children. Acta Linguistica Hungarica, 46(3-4): 289-316.

Sanyal, K. (2007): Rethinking Capitalist Development: Primitive Accumulation, Governmentality and Post-colonial Capitalism. London - New York - New Delhi: Routledge.

Szalai J. (2007): Nincs két ország. Társadalmi küzdelmek az állami (túl) elosztásért a rendszerváltás utána Magyarországon. Budapest: Osiris Kiadó.

Szalai J. (2010): A szabadságtalanság bővülő körei. Az iskolai szegregáció társadalmi „értelméről”. Esély, 21(3): 3-22.

Szombati, K. (2018): The Revolt of the Provinces. Anti-Gypsyism and Right-Wing Politics in Rural Hungary. New York: Berghahn Books.

Szőke J. (2016): Első a „modell”. In Fejes J. B. - Lencse M. - Szű́cs N. (szerk.): Mire jó a tanoda? Szeged: Motiváció Oktatási Egyesület.

Szúcs N. (2015): A TanodaPlatform bemutatása. Taní-tani Online, 2015. 05. 04.

Váradi M. M. (2019): Elméleti kaleidoszkóp - a migrációs tapasztalatok értelmezési lehetőségei. In uő. (szerk.): Migráció alulnézetből. Budapest: Argumentum Kiadó.

Virág T. (2010): Kirekesztve. Falusi gettók az ország peremén. Budapest: Akadémiai Kiadó.

Virág T. (2015): Bevezető. In uő. (szerk.): Törésvonalak. Szegénység és etnicitás vidéki terekben. Budapest: Argumentum, 7-27.

Virág T. (2020): Demográfiai polarizáció, térbeli és társadalmi marginalizáció két zsugorodó középvárosban . Szociológiai Szemle, 30(2): 27-49.

Wacquant, L. (2008): Urban Outcast: A Comparative Sociology of Advanced Marginality. London: Polity Press.

Wallerstein, I. (2000): The Essential Wallerstein. New York: The New Press.

Zolnay J. (2020): Tér-vakság. Oktatási stratégiák a városi zsugorodás és a tanulói létszám csökkenésének időszakában. Szociológiai Szemle, 30(2): 96-114. 